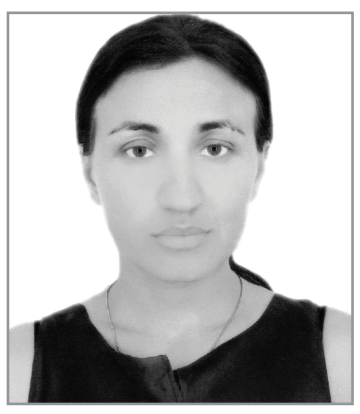

\author{
Tetiana Plachkova* \\ assistant of Odessa State University \\ of Internal Affairs \\ (Odessa, Ukraine) \\ ORCID: https://orcid.org/0000-0001-5316-5413
}

*Tetiana Plachkova, assistant of Odessa State University of Internal Affairs (1, Uspenska St., Odessa, Ukraine).

\title{
PROVIDING NAVIGATION SAFETY AT SEAPORTS OF UKRAINE: SOME ASPECTS OF STATE ADMINISTRATION
}

\section{ЗАБЕЗПЕЧЕННЯ БЕЗПЕКИ СУДНОПЛАВСТВА У МОРСЬКИХ ПОРТАХ УКРАЇНИ: ОКРЕМІ АСПЕКТИ ДЕРЖАВНОГО АДМІНІСТРУВАННЯ}

\section{ABSTRACT}

State administration in the field of ensuring the safety of navigation is an essential direction of the state's activity, the legal basis of which are the norms of international agreements. The leading role of the state and its bodies in the organizationallylegal provision of maritime safety in seaports is a recognized standard of world navigation. At all times, the port' states were responsible for the safety and security of ships in its own ports, including regulation and reliable and effective maintenance of navigation safety in them. Harbor Masters - as the main, appointed by a state, officials in seaports - are guarantors of the safety requirements of navigation on them. The administrative and legal component of the safety of navigation is the direct involvement of the state (its bodies and officials) in the organization and the legal regulation of this sphere. The bases of such state administration are stipulated in the norms of the international agreements, which became part of the national legislation 
of Ukraine, and are, in essence, the standards of such provision. At the same time, not always applicable mechanisms of public (state) administration are adequate to the developed situation and correspond to the world practice of navigation, may cause misunderstandings and need to be solved at the present time.

The key words: state administration, maritime safety, navigation, seaports, harbor masters.

The leading role of the state and its bodies in the organizationally-legal provision of maritime safety in seaports is a recognized standard of world navigation. At all times, the port' states were responsible for the safety and security of ships in its own ports, including regulation and reliable and effective maintenance of navigation safety in them. Harbor Masters - as the main, appointed by a state, officials in seaports - are guarantors of the safety requirements of navigation on them. Carrying out their duties is contributed to ensuring the safety of navigation, not only in individual ports, but also throughout the world. This is ensured through careful monitoring of the technical and operational status of ships, the granting of port clearance permits only to those that meet the requirements of safe navigation. In this case, the captains of sea ports are important, but only one of many components of a system of state administration of the safety navigation.

The works of L. V. Valueva, S. V. Kivalov, V. V. Serafimov, V. V. Ustinov, N. O. Fedchun, etc. are devoted to various aspects of organizationally-legal security of navigation at sea ports, but their research in terms of new problems of state administration of this sphere has not yet been updated and defines the direction and the main purpose of this article - the definition of legal and organizational basis and the definition of certain problematic aspects of the state Administration of safety of navigation in seaports of Ukraine.

State administration in the field of ensuring the safety of navigation is an essential direction of the state's activity, the legal basis of which are the norms of international agreements, the consent of which is obligatory for Ukraine provided by the Verkhovna Rada (the Article 9 of the Constitution of Ukraine). Thus, the United Nations Convention on the Law of the Sea of 1982 (hereinafter referred to as UNCLOS'82) defines the leading role of the state and its government (Administration) in the field of ensuring the safety of navigation, as evidenced by the norms and other, numerous international agreements. For example, according to the Article 94 "Duties of the flag State" UNCLOS'82, each State shall, with respect to ships flying its flag, take the necessary measures to ensure safety at sea. The scope of 
such activities includes the mandatory inspection by a qualified surveyor of each ship prior to registration and subsequently at appropriate intervals (the parts 3 and 4).

In accordance with Section 13 of the Management Requirements for Safety and Prevention of Pollution of the International Code for the Safe Operation of Ships and Pollution Prevention, a ship must be operated by a company that has received a document of compliance with the safety requirements relating to this ship. This document must be issued by the Administration (i.e. the government of a state under whose flag a ship has the right to sail) or an organization recognized by the Administration (or the government of a country) with which a company conducts its business on behalf of the Administration. The preamble to SOLAS even specifically states that it is the "Contracting Governments" (and not the "Parties", as in most international agreements) to conclude this Convention, and the articles state that it is they (governments) commit themselves to fulfill its norms (the Articles 1, 3, 5, etc.).

The purpose of the International Maritime Organization (IMO), in accordance with the Article 1 of the Convention is the provision of a mechanism for the cooperation of Governments in the field of government regulation and measures relating to technical issues relating to international trade shipping, in particular the encouragement and promotion of the adoption by all countries of high practicable standards in matters relating to maritime safety. According to its status and functions, the IMO is a technical organization and its main task is to develop standards for the safety of navigation, marine protection and protection of the marine environment from pollution from ships, as well as the establishment of mechanisms for the introduction and implementation of these international standards. The rules and the regulations developed by the IMO are addressed to administrations and governments, with most of them being shipowners, ship operators and seafarers. But, the implementation of all necessary steps to ensure proper observance of the rules, in accordance with the Article 94 of the UNCLOS' 82 is the responsibility of the state itself (Vasil'ev, 2011, p. 43).

One of the main bodies of the IMO is the Maritime Safety Committee, which, together with the Assembly and the Council, was established with the adoption of the Convention on the International Maritime Organization of 1948. According to the Article 28 of this Convention, the Maritime Safety Committee shall consider any matters within the scope of the IMO concerned with aids to navigation, construction, equipment and supply of 
vessels, the provision of ships with crew from a safety standpoint, rules for the prevention of collision of ships, handling of dangerous cargoes, maritime safety regulations, hydrographic information, log-books and navigational records, marine casualty investigation, salvage and rescue of property and people at sea, and any other issues that directly affecting maritime safety.

The Committee is currently dealing with all issues related to maritime safety, solving the problems of marine protection and the fight against piracy and armed robbery of ships, the issue of cybernetic security, electronic navigation and modernization of the Global Maritime Distress System, and to ensure safety of navigation. The Committee is also responsible for addressing the human factor, amendments to the Convention on Standards for the Training, Certification and Watchkeeping of Seafarers (Maritime Safety Committee of the International Maritime Organization).

At the same time, even under the conditions of paying much attention to the issues of ensuring the safety of navigation at the IMO level, the accident rate of the vessels did not decrease, and the IMO repeatedly noted that the non-fulfilment of the provisions of the mandatory documents by vessels is due to the fact that the control of the administrations of vessels of its flag is insufficient (Vasil'ev, 2011, p. 43). This is the disaster of the Amoco Cadiz tanker on March 16, 1978, in the English Channel, which resulted in the leakage of 1604500 barrels of oil and the irreversible environmental change in the area of the tanker flood (Vlasov, Buev, 2016, p. 107), stipulated the adoption of the Paris Memorandum of Understanding on port state control in the European region and the strengthening of the port state in compliance with its provisions, in accordance with the requirements of the safety standards of navigation, has yielded a significant result.

In accordance with the model of this memorandum, regional memoranda were adopted, in particular, the Memorandum of Understanding on Port State Control in the Black Sea Region (the Black Sea Memorandum), which obliged the Administration (for Ukraine, in accordance with Annex 1 to the Memorandum - Inspection of Ukraine on Shipping Safety) to establish and maintain an effective port State control system in order to ensure, without discrimination of the flag, that foreign merchant ships visiting the ports of their States comply with the norms that established: the 1966 International Load Lines (Load Lines 66), the International Convention for the Safety of Life at Sea 1974 (SOLAS 74), the International Convention for the Prevention of Pollution from Ships 1973, as amended by the 
Protocol 1978 thereto (MARPOL 73/78); the International Convention on Standards of Training, Certification and Watchkeeping 1978 (STCW 78), the Convention on the International Regulations for Preventing Collisions at Sea 1972 (COLREG 72), the International Convention on Tonnage Measurement 1969 (TONNAGE 69), the Convention on minimum standards for merchant ships in 1976 (№147).

Organization of control, in particular port state control or others, is an integral part of public administration in the field of safety in general and the safety of navigation in particular, since such administration entails the responsibility of a state to society and citizens for the application of appropriate measures (Skrynnik, 2012, p. 259). In addition, in order to achieve the safety of navigation, states should establish a system of bodies for the maintenance, control and supervision of the implementation of rules for safe navigation of vessels (Vandanov, 1974).

Thus, the emphasis in the rules of international agreements on the leading role of the state in the field of ensuring the safety of navigation determines its decisive role as the fundamental regulator and controlling influence exercised through specially authorized state bodies (governments etc.). The implementation of the norms of international agreements on the safety of navigation can not be carried out without the help of the domestic administrative organizationally - legal mechanism, a certain system of legislation and state bodies, the basis of which are the rules of administrative law, which determine the boundaries and vectors of management influence. And, the reliance on the authorities of the state on the control of ships, in particular, in the area of observance of the requirements of safety of navigation, testifies to the recognition of the leading role of a state in this sphere. The connection between national legislation and the rules of international agreements in the maritime sector is most evident precisely in the field of ensuring the safety of navigation: the internal legal and organizational mechanisms for its provision must comply with internationally agreed requirements (standards). Indeed, joining any international document means not only the recognition of the relevant norms, but also the obligations of the state to comply with these rules, which requires a series of organizational measures aimed at establishing a competent maritime administration, national control and inspection bodies with special competence for the safety of navigation. The effective exercise of the jurisdiction of each state over ships under its flag and the provision of real communication is an effective means of ensuring the safety of navigation (Pruss, Boevich, Korotkij, 2001, p. 38-39). 
As O. K. Zhudro and Yu. H. Dzhavad, with the development of world shipping, there was a need for the existence of a significant number of the international rules, mainly technical and organizationally - technical, related to ensuring the safety of navigation, preventing oil pollution of the sea... These rules transmitted the form of administratively - legal forms in order to ensure their mandatory observance by all states, organizations and citizens who took part in international shipping (Zhudro, Dzhavad, 1974, 88).

In accordance with the Regulation on the State System for the Safety of Navigation of Shipping approved by the Resolution of the Cabinet of Ministers of Ukraine, dated 7.10.2009 №1137, the state system of navigation safety management is a set of subjects, engaged in coordinated measures in the field of navigation, aimed at preventing the occurrence and mitigation of consequences of accidents that can cause damage to the health and life of people, the environment and property. The subjects of this system are: the executive authorities, the state pilot service, the service of regulating the movement of ships, the marine emergency rescue service, state enterprises, institutions and organizations that carry out activities in the field of navigational and hydrographic navigation provision, state enterprises engaged in activities in the field of maritime communication and telecommunications, river information system; state enterprises servicing navigable sea and river routes; state classification societies; seaports; state sectoral design and research institutions; state enterprises, institutions and organizations whose activities are related to the safety of navigation.

In order to improve the functioning of the state navigation management system by the order of the Ministry of Infrastructure of Ukraine from 26.06.2013 №426, the Sector Safety Security Program for 2014-2018 was approved, according to which the main causes of accidents on the sea transport were recognized: incompleteness of the reform of the control system of the sphere of security navigation safety; the presence of significant gaps in the national regulatory framework for shipping safety; lack of implementation in the national legislation of Ukraine of relevant norms, standards, rules and other IMO instruments, as well as the amendments to international treaties; the insufficient effectiveness of surveillance activities in the field of navigation safety, etc.

The main directions and tasks of the Program were defined: the fight against acts of violence on sea and river transport, protection of the environment, safety of navigation (the improvement of the existing system of management of the sphere of safety of navigation in order to bring it in 
line with the requirements of the international conventions; elaboration, improvement and development the regulatory framework for navigation safety and bringing it in line with international requirements; improving the system of state and technical supervision over compliance with the requirements of international treaties and legislation of Ukraine, rules of safety of navigation on ships, shipping companies, sea and river ports, territorial sea and inland waterways of Ukraine; creation of a system for informing shipping companies, regardless of ownership, on changes in national and international legislation on shipping safety, as well as emergency events and measures to prevent them; further upgrading of coastal systems of technical and information security of navigation; creation of a single database (registers) of seamen's documents; improvement of the material and technical base of practical and training of marine and river fleet specialists; ensuring safe transportation of dangerous goods by sea and river transport; the organization of a special training in sea ports for the management personnel, specialists and workers involved in the transport or acceptance of dangerous cargo), the improvement of the national search and rescue system at sea.

In order to implement the Program by the Order of the Ministry of Infrastructure of Ukraine dated November 28, 2013 №960, the Plan of measures of the Sector Safety Program for ensuring navigation safety for 2014-2018 was approved, which was envisaged, in particular, in the field of ensuring the safety of navigation, work in 4 main areas: special training for floating crew and personnel of coastal services, certification of state enterprises and institutions (clauses 3.1, 3.5, 3.6, 3.11, 3.12, 3.17, 3.19-3.22), supervision of ships (clauses 3.2, 3.3, 3.4, 3.14), translation and purchase of official international documents (clauses 3.7-3.9, 3.18), preparation for liquidation of emergency situations (p. 3.10, 3.13, 3.15, 3.16). Taking into account the leading role of the "human factor" in ensuring the safety of navigation, most of the directions in the Action Plan are devoted to the training of the floating crew and coastal personnel, the certification of state-owned enterprises and institutions in this area. New similar documents have not yet been adopted.

Accordingly, in compliance with the norms of the Black Sea Memorandum, by the order of the Ministry of Transport of Ukraine of 17.07.2003, №545, approved the Rules for controlling vessels in order to ensure the safety of navigation, according to paragraph 1.5 , in order to ensure the safety of navigation and the prevention of pollution from ships, 
all vessels that are located in the sea ports of Ukraine, are subject to obligatory control of the inspector of the seaport captain's service and the selective control of the port state control officer. The latter, in accordance with clause 1.4 of this Regulation, are officials of the Maritime Administration, the State Fisheries Agency of Ukraine or the service of the captain of the seaport of Ukraine, which, in accordance with the Regulation on the captain of the seaport and the service of the seaport captain, approved by the Order of the Ministry of Infrastructure of Ukraine dated 27.03.2013, №190, is a part of the Maritime Administration of Ukraine. It is headed by the captain of the seaport, who is appointed to the post and dismissed by the Ministry of Infrastructure of Ukraine on the submission of the Maritime Administration. The captain of the seaport is subordinate to the Head of the Maritime Administration. Consequently, state authorities and their officials are entrusted with the Port State Control (Port State Control) functions. At the same time, we must recall that in the end of 2018 - beginning of 2019 in the ports of Ukraine there was a parallel execution of duties by port captains appointed by the newly established Maritime Administration of Ukraine and the Administration of Seaports of Ukraine (in accordance with the previously existing legislation). Thus, the CMS of Ukraine stipulates that the organization and safety of navigation in the seaport shall rely on the administration of the sea ports of Ukraine (Part 1, the Article 74). State supervision of maritime safety at a seaport, is carried out by the captain of a seaport at approaches to it and in adjacent water areas.

The boundaries of the surveillance zone, which are subject to the powers of a seaport captain to carry out state supervision of the safety of navigation, are determined by the central executive authority, which ensures the implementation of state security policy at sea and river transport. State supervision of maritime safety at sea terminals located within the territories and water areas separated from the main territory and the water area of the relevant seaport shall be carried out by a separate subdivision of the service of a seaport captain. A captain of a seaport and a seaport captain's office operate on the basis of a provision approved by the central executive authority, which ensures the formation and implementation of state policy in the areas of sea and river transport (the Article 75).

According to the Part 4 of the Article 14 of the Law of Ukraine of 17.05.2012 "On Sea Ports of Ukraine", the safety of navigation in the water area of the seaport is ensured by the administration of the sea ports of Ukraine, owners of sea terminals and hydraulic structures, shipowners, 
and other business entities operating in the seaport, in accordance with the legislation and regulations defined by the mandatory regulations on the port. And, in accordance with the provisions of the Regulation on the captain of the seaport and the service of the seaport captain, which acted prior to the amendments in accordance with the Order of the Ministry of Infrastructure of Ukraine dated August 6, 2018, №354 "On Approval of Amendments to Certain Regulatory Acts of the Ministry of Transport of Ukraine, the Ministry of Transport and communications between Ukraine and the Ministry of Infrastructure of Ukraine", the seaport captain's service was part of the administration of the sea ports of Ukraine, and the captains were appointed and dismissed by the Ministry of infrastructure of Ukraine. In accordance with the Regulation on the State Service for Marine and River Transport of Ukraine, approved by the Resolution of the Cabinet of Ministers of Ukraine, dated September 6, 2017, №1095, the head of the Maritime Administration is subordinate to the captains of seaports (p. 22 of the clause 11), the Maritime Administration prepares the submission to the Ministry of Infrastructure of the appointment and dismissal of the seamen's captains (p. 53 of the clause 4).

At the same time, since the beginning of its functioning, the Maritime Administration issued several orders for the announcement of a competition for vacancies in the civil service of category "B" of the heads of the control (supervision) department for the safety of navigation on the sea and river transport in ports - the captains of the seaports of the relevant departments and their deputies [the orders №109 of 10.30.2018, №149 dated November 29, 2018, №2 dated January 3, 2019]. Taking into account the name, the positions of captains of seaports are in the structure of the relevant departments of the Maritime Administration. However, earlier (in September 2018), the Ministry of Infrastructure reported that the captains of seaports will still be subordinated to the Administrations of seaports (a competition has been announced for the captains of 13 seaports of Ukraine).

In January 2019, on the official website of the Maritime Administration, the notice disclosed the information on the appointment of captains of certain seaports of Ukraine (Certified captains of certain seaports of Ukraine). In this case, the captains of seaports (Port of Captain's Service, Harbor Service) continued to operate. In connection with the crisis situation around the appointment of other captains of seaports in Ukraine, on January 24, 2018, at the Ministry of Infrastructure of 
Ukraine, on the initiative of the Federation of Transport Employers of Ukraine, under the chairmanship of the Director of the Department for the Reforming and Operation of Marine and River Transport of the Ministry O.G. Basyuk, a meeting was held to discuss of the issue of the reorganization of the services of the captains of the seaports of Ukraine, which is carried out in accordance with the orders of the Ministry of Infrastructure, the Maritime Administration of Ukraine, on a separate commission from the Head of the State Enterprise "ASPU".

During the meeting, the idea was expressed that, in accordance with the ongoing measures to reorganize the services of the captains of sea ports of Ukraine, without the corresponding amendments to the Law of Ukraine "On Sea Ports of Ukraine", the Code of Merchant Shipping of Ukraine, two service captains should be established in Ukraine. One will be subordinated to ASPU, another - to the Maritime Administration of Ukraine. In order to resolve the issue, the Federation, together with its affiliated organizations, has proposed the Infrastructure to cancel Paragraph 33 of the Order of the Ministry of Infrastructure №354 dated August 6, 2018 "On Amendments to Certain Orders of the Ministry of Transport of Ukraine, the Ministry of Transport and Communications of Ukraine and the Ministry of Infrastructure of Ukraine", which provides for the amendments to clause 1.1 of the Regulation on the captain of a seaport and the service of a seaport captain, which provides that the service of a seaport captain is a part of the Maritime Administration countries.

Simultaneously, the Ministry of Infrastructure was invited to initiate as soon as possible the issue of amending the Code of Merchant Shipping of Ukraine, the Law of Ukraine "On Sea Ports of Ukraine" regarding the determination of the powers and subordination of the captains' services, the division of responsibilities between the Maritime Administration of Ukraine and the ASPU (On the Reorganization of Port Captain Services).

In the current situation, we must support the expressed positions of industry experts that the existence of two captains of seaports in Ukraine is a cause for considerable concern and misunderstanding among representatives of the maritime community, because when visiting Ukrainian ports, captains and shipowners (mainly ships under foreign flags) need to interact with two captains of ports, which is not present anywhere in the world, and official positions are expressed only by one state administration in this area - the Maritime Administration, and the Administration of seaports of Ukraine refrain from commenting on this issue. This indicates a significant 
degradation of the existing management system of one of the leading sectors of the state's economy, and such "dual power" is an element of deliberate discrediting of the long-awaited central body of water transport management (the Maritime Administration of Ukraine), which the industry has been waiting for many years (Vas'kov, 2019).

In accordance with the Regulation on the Ministry of Infrastructure of Ukraine, approved by the Resolution of the Cabinet of Ministers of Ukraine, dated June 30, 2015, №460, this Ministry is the main body in the system of central executive authorities that provides for the formation and implementation of state policy, in particular, on safety issues in maritime transport, as well as state supervision (control) for safety in marine transport (except for the safety of navigation of vessels of the fleet of fisheries) (Part 2, Clause 1). The state supervision (control) for maritime safety of fishing fleet vessels falls within the scope of the powers of the State Fisheries Management Agency of Ukraine, in accordance with the Regulation on which the State Agency of Land Resources is a central executive body whose activities are directed and coordinated by the Cabinet of Ministers of Ukraine through the Minister of Agrarian Policy and Food and which implements state policy in the field of fish industry and fishing industry, protection, use and reproduction of water bioresources, regulates fishing, safety of navigation of ships of a fishing fleet (clause 1). The State Fisheries Agency carries out the state control over the safety of navigation of the fleet of the fishing industry; cooperates with the Fisheries Committee of the Food and Agriculture Organization of the United Nations (FAO), foreign authorities and international fisheries management organizations, aquaculture management in the field of maritime safety, prevention of environmental pollution, protection of labor in the fisheries sector (Provisions 19, 52 of the Resolution).

Thus, the administrative and legal component of the safety of navigation is the direct involvement of the state (its bodies and officials) in the organization and the legal regulation of this sphere. The bases of such state administration are stipulated in the norms of the international agreements, which became part of the national legislation of Ukraine, and are, in essence, the standards of such provision. At the same time, not always applicable mechanisms of public (state) administration are adequate to the developed situation and correspond to the world practice of navigation, may cause misunderstandings and need to be solved at the present time. 


\section{REFERENCES}

Convention on the International Maritime Organization 1948 (United Nations). United Nations Treaty Collection. Retrieved from: https://reaties.un.org/Pages/ViewDetails. aspx?src=IND\&mtdsg_no=XII-1\&chapter=12\&clang=_en

Komitet z bezpeky na mori Mizhnarodnoi morskoi orhanizatsii [Maritime Safety Committee of the International Maritime Organization]. Ofitsiinyi sait Morskoi poshukovo-riatuvalnoi sluzhby. [The official website of the Marine Search and Rescue Service]. Retrieved from: http://www.sar.gov.ua/ua/pressroom/news/418-komitet-z-bezpeki-na-mori-mizhnarodnojimorskoji-organizatsiji [in Ukrainian].

Konstytutsiia Ukrainy 1996 (Verkhovna Rada Ukrainy). [Constitution of Ukraine (Verkhovna Rada of Ukraine)]. Vidomosti Verkhovnoi Rady Ukrainy [Statements of the Verkhovna Rada of Ukraine], 30, 141. [in Ukrainian].

Memorandum pro vzaiemorozuminnia shchodo kontroliu derzhavoiu portu $u$ Chornomorskomu rehioni 2000 (derzhavy-uchasnytsi) [Memorandum of Understanding on Port State Control in the Black Sea Region 2000 (States Parties)]. Ofitsiinyi visnyk Ukrainy. [Official Bulletin of Ukraine], 2010, 96, 3428. [in Ukrainian].

Nakaz pro zatverdzhennia Haluzevoi prohramy zabezpechennia bezpeky sudnoplavstva na 2014-2018 roky, 2013 (Ministerstvo infrastruktury Ukrainy) [Order for approval of the Sector Safety Program for the Security of Shipping for 2014-2018, 2013 (Ministry of Infrastructure of Ukraine)]. IAS Konsultant. Retrieved from: http://consultant.parus. ua/?doc $=08$ OJR2F9BD [in Ukrainian].

Nakaz pro zatverdzhennia Zmin do deiakykh normatyvno-pravovykh aktiv Ministerstva transportu Ukrainy 2018 (Ministerstvo infrastruktury Ukrainy) [Order to approve Amendments to certain normative legal acts of the Ministry of Transport of Ukraine 2018 (Ministry of Infrastructure of Ukraine)]. Ofitsiinyi visnyk Ukrainy. [Official Bulletin of Ukraine], 69, 2347. [in Ukrainian].

Nakaz pro zatverdzhennia Planu zakhodiv Haluzevoi prohramy zabezpechennia bezpeky sudnoplavstva na 2014-2018 roky, 2013 (Ministerstvo infrastruktury Ukrainy) [Order on Approval of the Plan of Measures of the Sector Safety Program for the Safety of Navigation for 2014-2018, 2013 (Ministry of Infrastructure of Ukraine)]. Ofitsiinyi sait Ministerstva infrastruktury Ukrainy. [Official site of the Ministry of Infrastructure of Ukraine]. Retrieved from: http://mtu.gov.ua/documents/144.html [in Ukrainian].

Nakaz pro zatverdzhennia Polozhennia pro kapitana morskoho portu ta sluzhbu kapitana morskoho portu 2013 (Ministerstvo infrastruktury Ukrainy) [Order on Approval of the Regulations on the Captain of the Seaport and the Captain of the Seaport 2013 (Ministry of Infrastructure of Ukraine)]. Ofitsiinyi visnyk Ukrainy. [Official Bulletin of Ukraine], 36, 1284. [in Ukrainian].

Nakaz pro zatverdzhennia Pravyl kontroliu suden z metoiu zabezpechennia bezpeky moreplavstva 2003 (Ministerstvo transportu Ukrainy) [Order on approval of the Rules for the control of ships in order to ensure the safety of navigation 2003 (Ministry of Transport 
of Ukraine)]. Ofitsiinyi visnyk Ukrainy. [Official Bulletin of Ukraine], 2004, 13, 915. [in Ukrainian].

Nakaz pro oholoshennia konkursu na zainiattia vakantnykh posad derzhavnoi sluzhby katehorii "B" 2018 (Derzhavna sluzhba morskoho ta richkovoho transportu Ukrainy) [The order for the announcement of a competition for vacant posts in the civil service category "B" 2018 (State Service for Marine and River Transport of Ukraine)]. Ofitsiinyi sait Derzhavnoi sluzhby morskoho ta richkovoho transportu Ukrainy. [Official site of the State Service for Marine and River Transport of Ukraine]. Retrieved from: https://marad.gov.ua/ ua/npa/pro-ogoloshennya-konkursu-na-zajnyattya-vakantnih-posad-derzhavnoyi-sluzhbikategoriyi-b-109 [in Ukrainian].

Nakaz pro oholoshennia konkursu na zainiattia vakantnykh posad derzhavnoi sluzhby katehorii "B" 2018 (Derzhavna sluzhba morskoho ta richkovoho transportu Ukrainy) [The order for the announcement of a competition for vacant posts in the civil service category "B" 2018 (State Service for Marine and River Transport of Ukraine)]. Ofitsiinyi sait Derzhavnoi sluzhby morskoho ta richkovoho transportu Ukrainy. [Official site of the State Service for Marine and River Transport of Ukraine]. Retrieved from: https://marad.gov.ua/ ua/npa/pro-ogoloshennya-konkursu-na-zajnyattya-vakantnih-posad-derzhavnoyi-sluzhbikategoriyi-b-149 [in Ukrainian].

Nakaz pro oholoshennia konkursu na zainiattia vakantnykh posad derzhavnoi sluzhby katehorii "B" 2019 (Derzhavna sluzhba morskoho ta richkovoho transportu Ukrainy) [The order for the announcement of a competition for vacant posts in the civil service category "B" 2018 (State Service for Marine and River Transport of Ukraine)]. Ofitsiinyi sait Derzhavnoi sluzhby morskoho ta richkovoho transportu Ukrainy. [Official site of the State Service for Marine and River Transport of Ukraine]. Retrieved from: https://marad.gov.ua/ua/npa/pro-ogoloshennya-konkursu-na-zajnyattya-vakantnih-posadderzhavnoyi-sluzhbi-kategoriyi-b-2 [in Ukrainian].

Ob'javlen konkurs na zanjatie dolzhnostej kapitanov 13 morskih portov Ukrainy [A competition has been announced for the positions of captains of 13 sea ports of Ukraine]. Centr transportnyh strategij. [Center for transport strategies]. Retrieved from: https://cfts.org.ua/news/2018/11/12/obyyavlen_konkurs_na_zanyatie_dolzhnostey_ kapitanov_13_morskikh_portov_ukrainy_50444 [in Russian].

Paris Memorandum of Understanding on Port State Control 1982 (member states). Centre for International Law of National University of Singapore National University of Singapore. Retrieved from: https://cil.nus.edu.sg/wp-content/uploads/formidable/18/1982-Paris-Memorandum-of-Understanding-on-Port-State-Control.pdf

Postanova pro zatverdzhennia Polozhennia pro Derzhavne ahentstvo rybnoho hospodarstva Ukrainy 2015 (Kabinet Ministriv Ukrainy) [Regulation on Approval of the Regulation on the State Agency for Fisheries of Ukraine 2015 (Cabinet of Ministers of Ukraine)]. Ofitsiinyi visnyk Ukrainy. [Official Bulletin of Ukraine], 90, 3018. [in Ukrainian].

Postanova pro zatverdzhennia Polozhennia pro Derzhavnu sluzhbu morskoho ta richkovoho transportu Ukrainy 2017 (Kabinet Ministriv Ukrainy) [The Resolution on Approval of the 
Regulation on the State Service for Marine and River Transport of Ukraine 2017 (Cabinet of Ministers of Ukraine)]. Ofitsiinyi visnyk Ukrainy. [Official Bulletin of Ukraine], 2018, 10, 357. [in Ukrainian].

Postanova pro zatverdzhennia Polozhennia pro Derzhavnu systemu upravlinnia bezpekoiu sudnoplavstva 2009 (Kabinet Ministriv Ukrainy) [Regulation on Approval of the Regulations on the State Navigation Management System 2009 (Cabinet of Ministers of Ukraine)]. Ofitsiinyi visnyk Ukrainy. [Official Bulletin of Ukraine], 83, 2810. [in Ukrainian].

Postanova pro zatverdzhennia Polozhennia pro Ministerstvo infrastruktury Ukrainy 2015 (Kabinet Ministriv Ukrainy) [Regulation on Approval of the Regulation on the Ministry of Infrastructure of Ukraine 2015 (Cabinet of Ministers of Ukraine]. Ofitsiinyi visnyk Ukrainy. [Official Bulletin of Ukraine], 54, 1755. [in Ukrainian].

Pro reorhanizatsiiu Sluzhb kapitaniv portu [On the reorganization of the Harbor Master's Services]. Veb-sait Federatsii robotodavtsiv transportu Ukrainy. [Website of the Federation of Employers of Transport of Ukraine]. Retrieved from: http://frtukr.org/ua/home/ 101-ukrajinska/pres-tsentr/zmi-pro-frtu/1605-pro-reorganizatsiya-sluzhb-kapitaniv-portu [in Ukrainian].

Pruss, V.M., Boevich, V., Korotkij, T.R. (2001). Mezhdunarodno-pravovye aspekty bezopasnosti moreplavanija [International legal aspects of the safety of navigation]. Odessa, Latstar. [in Russian].

Pryznacheno kapitaniv okremykh morskykh portiv Ukrainy [Captains of certain seaports of Ukraine have been appointed]. Ofitsiinyi sait Derzhavnoi sluzhby morskoho ta richkovoho transportu Ukrainy. [Official site of the State Service for Marine and River Transport of Ukraine]. Retrieved from: https://marad.gov.ua/news/ [in Ukrainian].

Skrynnik, A.M. (2012). Mezhdunarodnyj i nacional'nyj kontrol' (nadzor) v sfere obespechenija bezopasnosti morskogo sudohodstva. Problemy pravovogo regulirovanija [International and national control (supervision) in the field of maritime safety. Problems of legal regulation]. Aktual'nye problemy rossijskogo prava. [Actual problems of Russian law], 2(23), 258-266. [in Russian].

Sluzhba kapitana portu [Harbor Master's Service]. Ofitsiinyi sait Administratsii Odeskoho morskoho portu. [Official site of the Administration of the Odessa seaport]. Retrieved from: http://www.port.odessa.ua/ua/poslugi/sluzhba-kapitana-portu [in Ukrainian].

Sluzhba kapitaniv portiv [Service Captains of Ports]. Ofitsiinyi sait Derzhavnoi sluzhby morskoho ta richkovoho transportu Ukrainy. [Official site of the State Service for Marine and River Transport of Ukraine]. Retrieved from: https://marad.gov.ua/ua/sluzhbakapitaniv-portiv [in Ukrainian].

The International Safety Management Code 1993 (IMO Assembly). Admiralty and Maritime Law Guide. Retrieved from: http://www.admiraltylawguide.com/conven/ismcode1993.html United Nations Convention on the Law of the Sea 1982 (United Nations). The official website of the UN. Retrieved from: http:/www.un.org/Depts/los/convention_agreements/texts/ unclos/unclos_e.pdf 
Vandanov, T.B. (1974). Obespechenie, kontrol' i nadzor za bezopasnost'ju moreplavanija [Ensuring, monitoring and supervising the safety of navigation]. Morskoj flot. [Navy], 12, 28-29. [in Russian].

Vas'kov, Ju. (2019). Car' Solomon skazal: "Kogda strana otstupit ot zakona, togda mnogo v nej nachal'nikov"... [Tsar Solomon said: "When a country retreats from the law, then there are a lot of bosses in it"]. Storinka Jurija Vas'kova u Feisbuk. [Page by Yuri Vaskov on Facebook]. Retrieved from: https://www.facebook.com/profile. php?id=100033523153824\& tn =\%2CdCH-R-R\&eid=ARBPGQVBozBrbeC8rvHGF MVhq4DCwJihCa4D_1N2Xo0iLUYq-hrKQ9CMQsTcZ8iQgCdydAm9_W2BK4b_\&hc ref=ARQ_GeE8UeBoGpKk84ztoTydg2T_aQxY4xkaKWuzyRi3cfiPSCkqC9UxXgCMU1 Pyn0o\&fref $=$ nf [in Russian].

Vasil'ev, V.Ja. (2011). Rasshirenie dejatel'nosti Rossii v ramkah Mezhdunarodnoj morskoj organizacii [Expansion of Russia's activities in the framework of the International Maritime Organization]. Transport Rossijskoj Federacii. [Transport of the Russian Federation], 4(35), 42-46. [in Russian].

Vlasov, A.B., Buev, S.A. (2016). Nekotorye voprosy kontrolja sudna v morskom portu [Some issues of control of the vessel in the seaport]. Vestnik AGTU. Ser: Morskaja tehnika i tehnologija. [Bulletin of ASTU. Marine technology and technology], 3, 107-112. [in Russian].

Zakon pro morski porty Ukrainy 2012 (Verkhovna Rada Ukrainy). [Law on Ukrainian Seaports 2012 (Verkhovna Rada of Ukraine)]. Ofitsiinyi visnyk Ukrainy. [Official Bulletin of Ukraine], 45, 1729. [in Ukrainian].

Zhudro, A.K., Dzhavad, Ju.H. (1974). Morskoe pravo [Maritime Law]. Moscow, Transport. [in Russian].

\section{АНОТАЦІЯ}

Плачкова Т. М. Забезпечення безпеки судноплавства у морських портах України: окремі аспекти державного адміністрування. - Стаття.

Державне адміністрування у сфері забезпечення безпеки мореплавства $є$ суттєвим напрямом діяльності держави, правовим підгрунтям якого є норми міжнародних угод. Провідна роль держави та іiі органів у організаційно-правовому забезпеченні безпеки судноплавства у морських портах $€$ визнаним стандартом світового мореплавства. У всі часи держави порту відповідали за схоронність та убезпечення суден у власних портах, включаючи регулювання і надійне та ефективне підтримання безпеки судноплавства у них. Капітани морських портів (Harbour Masters) - як головні, призначувані державою, посадові особи у морських портах - є гарантами дотримання вимог безпеки судноплавства у них. Виконання ними своїх обов'язків сприяє забезпеченню безпеки судноплавства не лише в окремих портах, а й в усьому світі. Це забезпечується завдяки пильному контролю технічного та експлуатаційного стану суден, надання дозволів на вихід суден з портів лише тим, що відповідають 
вимогам безпечного плавання. При цьому, капітани морських портів є важливим, проте лише одним з багатьох складників системи державного адміністрування безпеки мореплавства. Автор відзначає, що адміністративно-правова складова забезпечення безпеки мореплавства полягає у безпосередній участі держави (iї органів та посадових осіб) у організації та правовому регулюванні цієї сфери. Основи такого державного адміністрування передбачені у нормах міжнародних угод, що стали частиною національного законодавства України, та $є$, за своєю суттю, стандартами такого забезпечення. При цьому, не завжди застосовувані механізми публічного (державного) адміністрування $є$ адекватними складеній ситуації та відповідають світовій практиці мореплавства, можуть викликати непорозуміння та потребують на теперішній час негайного вирішення.

Ключові слова: державне адміністрування, безпека мореплавства, мореплавство, морські порти, капітани морських портів.

\section{АННОТАЦИЯ \\ Плачкова Т. М. Обеспечение безопасности судоходства в морских портах Украины: отдельные аспекты государственного админист- рирования. - Статья.}

Государственное администрирование в сфере обеспечения безопасности мореплавания является существенным направлением деятельности государства, правовую основу которого составляют нормы международных соглашений. Ведущая роль государства и его органов в организационно-правовом обеспечении безопасности судоходства в морских портах является признанным стандартом мирового мореплавания. Во все времена государства порта отвечали за сохранность и обеспечение безопасности судов в собственных портах, включая регулирование, надежное и эффективное обеспечение безопасности судоходства в них. Капитаны морских портов (Harbour Masters) - как главные, назначаемые государством, должностные лица в морских портах - это гаранты соблюдения требований безопасности судоходства в них. Выполнения ими своих обязанностей способствует обеспечению безопасности судоходства не только в отдельных портах, но и во всем мире. Это обеспечивается благодаря пристальному контролю технического и эксплуатационного состояния судов, предоставлению разрешений на выход судов из портов тем судам, которые сооответствуют требованиям безопасного плавания. При этом, капитаны морских портов являются важным, однако лишь одним из многих составляющих системы государственного администрирования безопасности мореплавания. Автор отмечает, что административно-правовая составляющая обеспечения безопасности мореплавания заключается в непосредственном участии государства (его органов и должностных лиц) в организации и правовом регулировании этой сферы. Основы такого государственного администрирования закреплены в нормах международных соглашений, ставших частью национального законодательства Украины, и являются, по сути, стандартами такого 
обеспечения. При этом, применяемые механизмы публичного (государственного) администрирования не всегда адекватны складывающейся ситуации и соответствуют мировой практике мореплавания, могут вызвать недоразумения и требуют в настоящее время незамедлительного разрешения.

Ключевые слова: государственное администрирование, безопасность мореплавания, мореплавание, морские порты, капитаны морских портов. 